\title{
DELINEATION OF STRUCTURAL PATTERNS OF SEDIMENTARY BASINS OF NORTHERN NILE DELTA, EGYPT, USED GRAVITY DATA.
}

\author{
Ibrahim Sh.A. ${ }^{1}$, Ghoneimi A. ${ }^{1}$, Abeer A.K. ${ }^{1}$, and Farrag Kh. ${ }^{2}$ \\ ${ }^{1}$ Geology Department, Faculty of Science, Zagazig University, Egypt. \\ ${ }^{2}$ Consultant Geophysicist.
}

\begin{abstract}
The present study is an attempt to delineate the regional structural framework and basin configuration of Northern Nile Delta, Egypt by analysis of gravity map. The study area is located, between Longitude $30^{\circ} 30^{\prime \prime}-32^{\circ} 00^{\prime \prime} \mathrm{E}$ and Latitude $31^{\circ} 00^{\prime \prime}-31^{\circ} 48^{\prime \prime} \mathrm{N}$. The least square polynomial technique is used to separate the Bouguer anomaly of the study area into its regional and residual components. The second order polynomial is taken as the optimum one to achieve the regional residual separation. The structural framework of the sedimentary basins is delineated using the Euler deconvelution technique, the detected fault systems are grouped into six major tectonic trends: Mediterranean trend (E-W trend), Syrian arc trend $\left(\mathrm{N} 45^{\circ}-65^{\circ} \mathrm{E}\right.$ trend), Najd trend ( $\mathrm{N} 65^{\circ} \mathrm{W}$ trend), Gulf of Suez trend (N 35 $-45^{\circ} \mathrm{W}$ trend), Aqaba trend $\left(\mathrm{N} 15^{\circ}-25^{\circ}\right.$ E trend) and North African trend (N-S trend). The constructed depth to the basement map illustrates a huge basin located in the central part of the study area. The depth ranges from $1400 \mathrm{~m}$ to $10460 \mathrm{~m}$.
\end{abstract}

\section{Introduction}

Neogene-Quaternary clastics sequences exist in the Nile Delta basins, which are prospective for petroleum and gas generation and accumulation, especially in the offshore and northern onshore areas (Zaghloul, et. al., 1977b). The main proven reservoir within the Miocene deltaic sequences, of the northern Delta basin, is Abu Madi sandstones (the Messinian Rocks) (Barakat and Dominik, 2010).

The goal of the present work is to describe the regional structural framework and basin configuration of northern Nile Delta. The present study is located in the northern area of the Nile Delta between Longitude $30^{\circ} 30^{\prime \prime}-32^{\circ} 00^{\prime \prime} \mathrm{E}$ and Latitude $31^{\circ} 00^{\prime \prime}-31^{\circ} 48^{\prime \prime} \mathrm{N}$, (Fig. 1). Initial way to pass a regional structural mapping in geophysical exploration is gravity (Dobrin, 1976).

The Bouguer gravity anomaly map is totality the effects of a number of subsurface structures present at several depths. The anomalies caused by shallow geological features (residual anomalies) must be separated from 
regional anomaly caused by deeper geological features (Dobrin, 1976, Nettleton, 1976 and Robinson, 1988).

The regional residual separation has been attained by using least square method. The correlation coefficients between each consecutive pair of residual maps are used in gravity interpretation (Abdel Rahman et. al., 1985). Magnetic or gravity data could be interpreted using Euler deconvolution, which is boundary discoverer and depth estimation. The gravity data, in grid shape, can be quickly interpreted through the Euler homogeneity relationship (Thompson, 1986, Reid, et. al., 1990 and Chenrai, et. al., 2010).

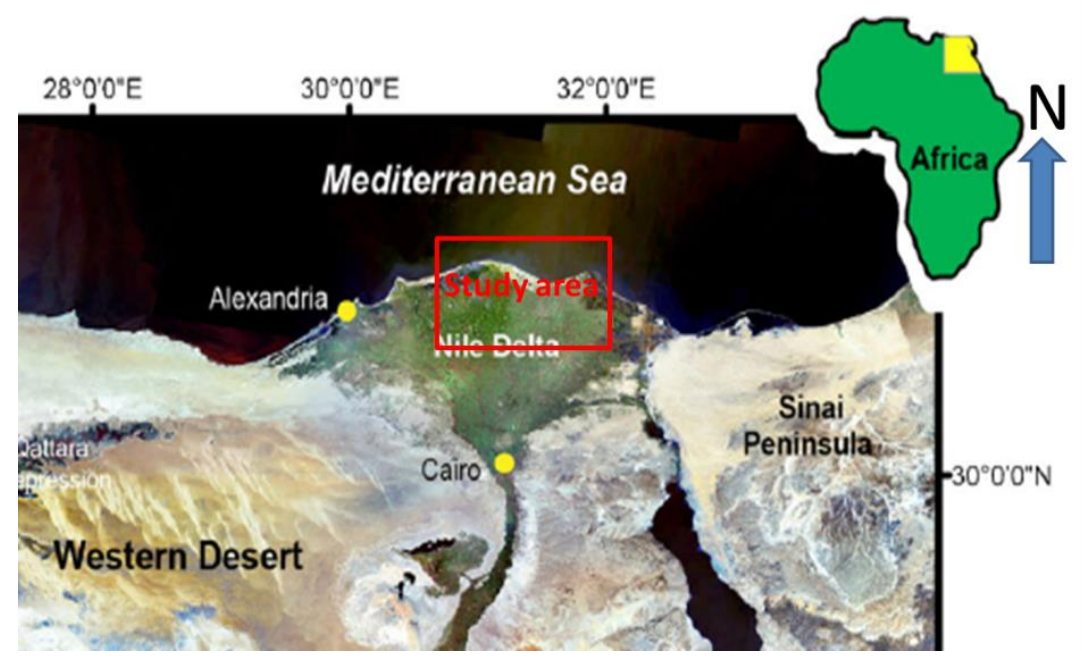

Figure (1): Location map of the study area.

\section{Geological settings}

The Nile Delta has in general a featureless surface with a northerly slope except for some limited topographic features such as the Khatatba positive structural and the westward Wadi El-Natrun negative element (Azzam, 1994). The geological knowledge of the Nile Delta is still slightly limited, as the country does not have any exposures of ancient rocks, since it is covered by Holocene soils. The best known exposures are the Tertiary and Mesozoic stratigraphic sequences shown along the margins of the delta and the Western Desert (Said, 1962 and Salem, 1976).

The Nile Delta is an ancient feature that began with the advance of the upper Pliocene and took its present shape with the commencement of the Pleistocene (Said, 1973).

Kostandi, (1959) indicated that the northern Egypt was covered by the Carboniferous sea. El- Gezeery, et al., (1972) said that in the Carboniferous sea approximately $1500 \mathrm{~m}$ of the Paleozoic sediments was deposited.

Mesozoic beds were penetrated only in a few wells across the center and southern portions of the Nile Delta because of the northward thickening of Tertiary section (Said, 1990). Sequences of Upper Jurassic to Oligocene were 
penetrated in wells near to the hinge line, including shore shelf and lagoonal deposits (Schlumberger, 1984, EGPC, 1994 and Kamel et. al. 1998).

A feature of elongated basins, during the Paleocene and Eocene time, probably extends to the region of the Nile Delta (Salem, 1976). Narrow elongated E-W trending basins, during The Early to Middle Eocene time, go with a distinct flexure zone in the mid-Delta area (Zaghloul, et al., 1999). Marine to fluvio-marine shales and sandstone interbedded sediments of Late Oligocene-Early Miocene age are represented by Tinie Formation (El-Heiny and Enani, 1996).

Neogene-Quaternary rock units, in the Nile Delta region, were classified environmentally to three sedimentary cycles (Zaghloul et al., 1977a). The Neogene-Quaternary subsurface succession in the northern part of the Nile Delta basin has been subdivided into eight formations arranged from base to top: Sidi Salem, Qawasim, Rosetta, Abu Madi, Kafr El-Sheikh, El-Wastani, Mit Ghamr and Bilqas formations (Rizzini et al. 1978, E.G.P.C. 1994 and El Heiny and Enani, 1996).

The generalized lithostratigraphic column, of the Nile Delta, was shown in figure (2) (Schlumberger, 1984).

The Pre-Miocene formations across the mid-delta area affected in the EastWest direction by Hinge Zone, located at about latitude $31^{\circ} \mathrm{N}$, of about 30-40 $\mathrm{Km}$ wide (Harms and Wray, 1990). The Hinge zone caused major facies changes between a platform and slope carbonates (EGPC, 1994).

The Nile Delta structurally includes the deep offshore Nile Delta province north of the continental shelf and the onshore Nile delta province. The Hinge Zone subdivided the onshore Nile Delta province into the South Nile Delta block and the North Nile Delta basins (Shata and El-Fayoumy, 1970; EGPC, 1994 and Kamel et al., 1998).

The north Nile Delta basin is structurally controlled by six main fault trends; Mediterranean trend (E-W trend), Syrian arc trend $\left(\mathrm{N} 45^{\circ}-65^{\circ} \mathrm{E}\right.$ trend), Najd trend $\left(\mathrm{N} 65^{\circ} \mathrm{W}\right.$ trend), Suez trend $\left(\mathrm{N} 35^{\circ}-45^{\circ} \mathrm{W}\right.$ trend), Aqaba trend (N $15^{\circ}-25^{\circ}$ E trend) and North African trend (N-S trend) (Said, 1962, ElShazly, 1966, Youseef, 1968, Abdel-Gawad, 1969, Meshref and El-Sheikh, 1973, Meshref et. al., 1980 and Meshref, 1982).

\section{Methodology}

Three methods are used for processing and interpretation of the gravity data (Sandwell satellite-derived gravity data); these are the Least-Squares, Euler deconvolution and Half Maximum amplitude.

Least-squares method is employed to detect a potential surface that corresponds to the observed gravity map. The intimacy of fit depends on the degree or order of the computation. The calculated surfaces are gone when the 
totality of the squares of the differences between it and the observed surface is a minimum, this method first suggested by DeLury (1950), was used by Oldham and Southerland (1955) and modified by Grant (1957), Nettelton (1976), Abdel Rahman et al., (1985 and 1991) and others.

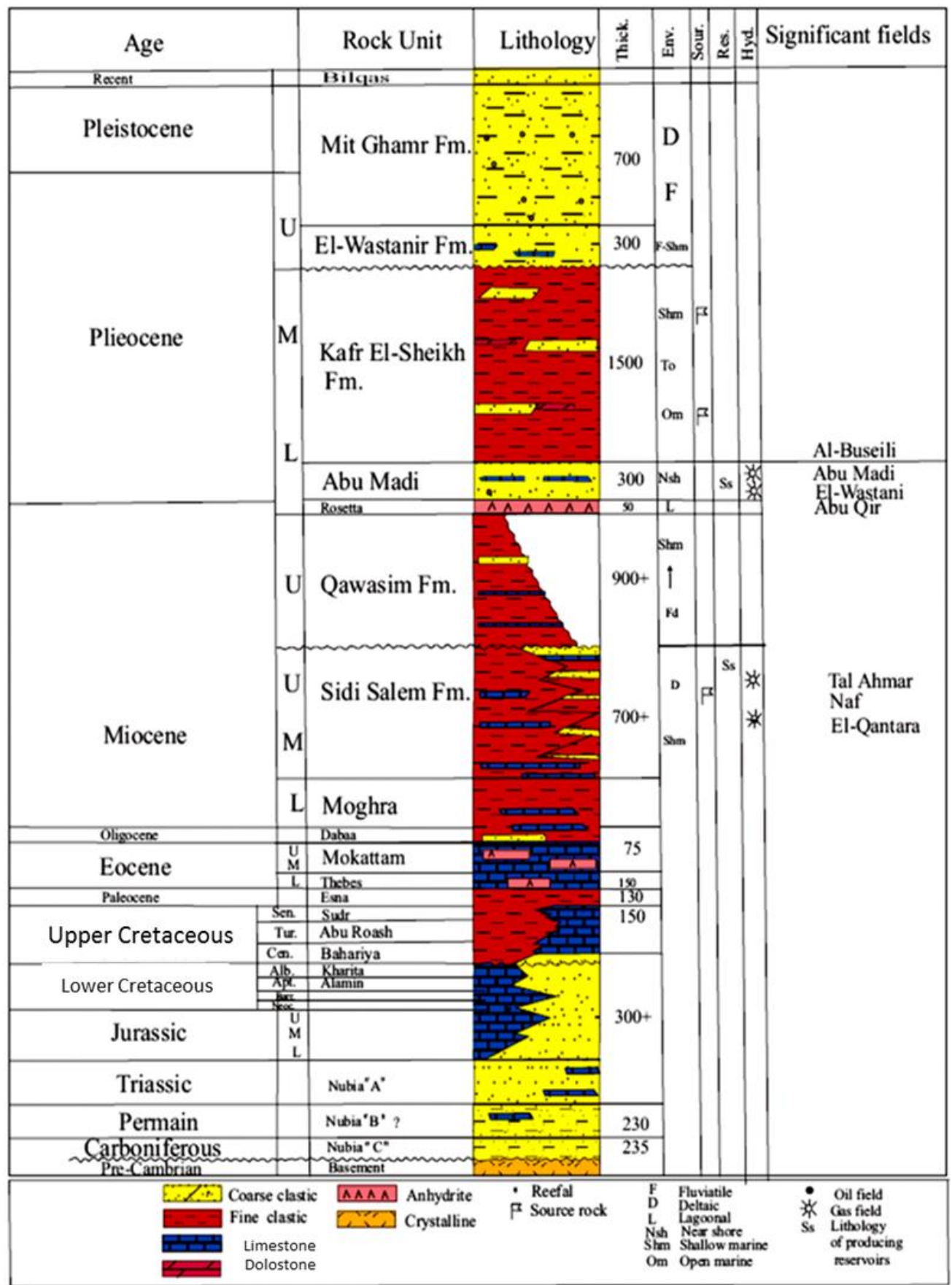

Figure (2): Generalized Lithostratigraphic column of the Nile Delta (after Schlumberger, 1984). 
The correlation coefficients between the sequential residual maps enable us to identify the optimum order of the regional surface and therefore the least distorted residual component. The residual map of the lower order in this well correlated doublet is considered the most plausible one and has been used for gravity interpretation (Abdel Rahman, et al., 1985).

The standard Euler deconvolution method resolves the data by solving Euler's homogeneity equation at each point in the data window (Thompson, 1986 and Reid, et al 1990). Only homogeneous functions could be solved by Euler deconvolution. The Euler's homogeneity relation has been written in the following form by Thompson (1986):

Where:

$$
\left(x-x_{0}\right) \frac{d f}{d x}+\left(y-y_{0}\right) \frac{d f}{d y}+\left(z-z_{0}\right) \frac{d f}{d z}=N(B-f)
$$

$x_{0}, y_{0}$ and $z_{0}$ : is the position of a gravity (or magnetic) source.

$f:$ is the total field detected at $\mathrm{x}, \mathrm{y}$ and $\mathrm{z}$.

$B$ : is the regional value.

$N$ : is the degree of homogeneity.

$\frac{d f}{d x}, \frac{d f}{d y}$ and $\frac{d f}{d z}$ are the first derivatives of $\mathrm{x}, \mathrm{y}$ and $\mathrm{z}$.

The degree of homogeneity explains the fall-off rate with distance for the field and explained as a structural index SI (Thompson, 1986). Euler deconvolution is widely applied to interpret profile or gridded gravity survey data. It estimates the depth and source location automatically by using a different structural index (SI) (Table 1) to each source type. Euler deconvolution can be usefully applied to gravity data. The gravity SI is less than the magnetic SI by one (FitzGerald et al., 2004).

Table (1): Structural Index for magnetic and gravity bodies (after FitzGerald et al., 2004).

\begin{tabular}{ccc}
\hline Source & Gravity SI & Magnetic SI \\
\hline Sphere & 2 & 3 \\
Horizontal cylinder (pipe) & 1 & 2 \\
Sill/dyke & 0 & 1 \\
Contact & -1 & 0 \\
\hline
\end{tabular}

The grid cell size, structural index and Euler window size are the important input parameters which effect on the resolution of depths. We will sometimes make several sets of Euler solutions, each with different parameters. The optimum structure index usually yields the tightest clustering of the solution. The choice of window size is a function of the grid cell size and should be 
selected to be large enough to incorporate a variation of gravity and small enough to avoid the effects from adjacent sources (Thompson, 1982, Reid et al. 1990 and Ravat, 1996).

Half maximum amplitude method was proposed by Logachive (1968). It calculates the depth (approximately) of the anomalous causative body by the following relation:

$$
\mathrm{H}=\frac{\left(x_{\frac{1}{4}}\right)^{2}-\left(x_{\frac{1}{2}}\right)^{2}}{2\left(x_{\frac{1}{2}}\right)} \times \text { scale }
$$

Where: $\mathrm{H}$ is the depth of the anomaly. $X_{\frac{1}{2}}$ : is the horizontal distance between points of maximum and the points of the half. $X_{\frac{1}{4}}$ : is the horizontal distance between points of maximum and the points of the quarter.

\section{Results and discussion}

\section{Least-squares polynomial method}

Five orders, in the Least-squares polynomial method, have been performed to separate the gravity anomaly into its regional and residual components. The correlation coefficients, between two residuals of sequential orders, are computed for the five orders (Table 2) to determine an optimum order of the polynomial, which represents the predominant regional trend in the data. The optimum order for the study area, which exemplifies the regional residual separation, is the second order polynomial, and so it is used as the best order for the gravity anomaly separation (Fig. 3).

The $\mathrm{E}-\mathrm{W}$ is the main trend direction for the second order regional polynomial trend surface, which increases from south to north and northwest. Two elongated negative anomalies present on the second order polynomial residual map located on the southwestern and northeastern regions, another elongated positive anomaly located between the two negative anomalies and both anomalies are trending northwest southeast.

Table (2): Correlation coefficients between residuals of each two consecutive orders.

\begin{tabular}{ccccc}
\hline orders & first & second & third & fourth \\
\hline first & 1 & & & \\
second & 0.682195 & 1 & & \\
third & & 0.801126 & 1 & \\
fourth & & & 0.682195 & 1 \\
fifth & & & & 0.600165 \\
\hline
\end{tabular}


(a)

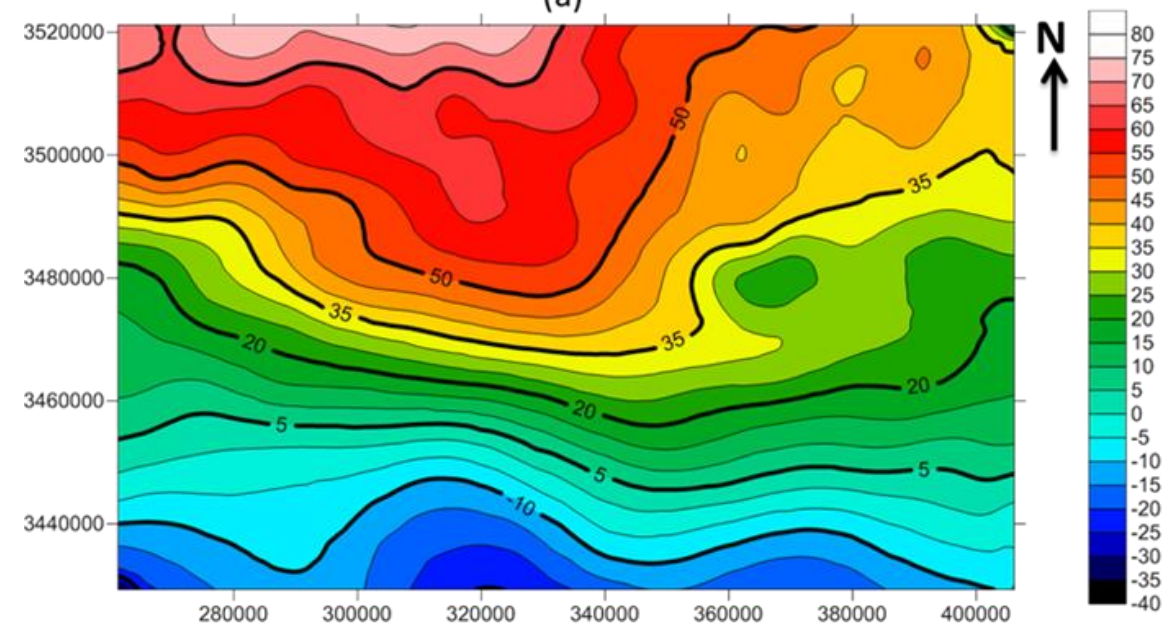

(b)
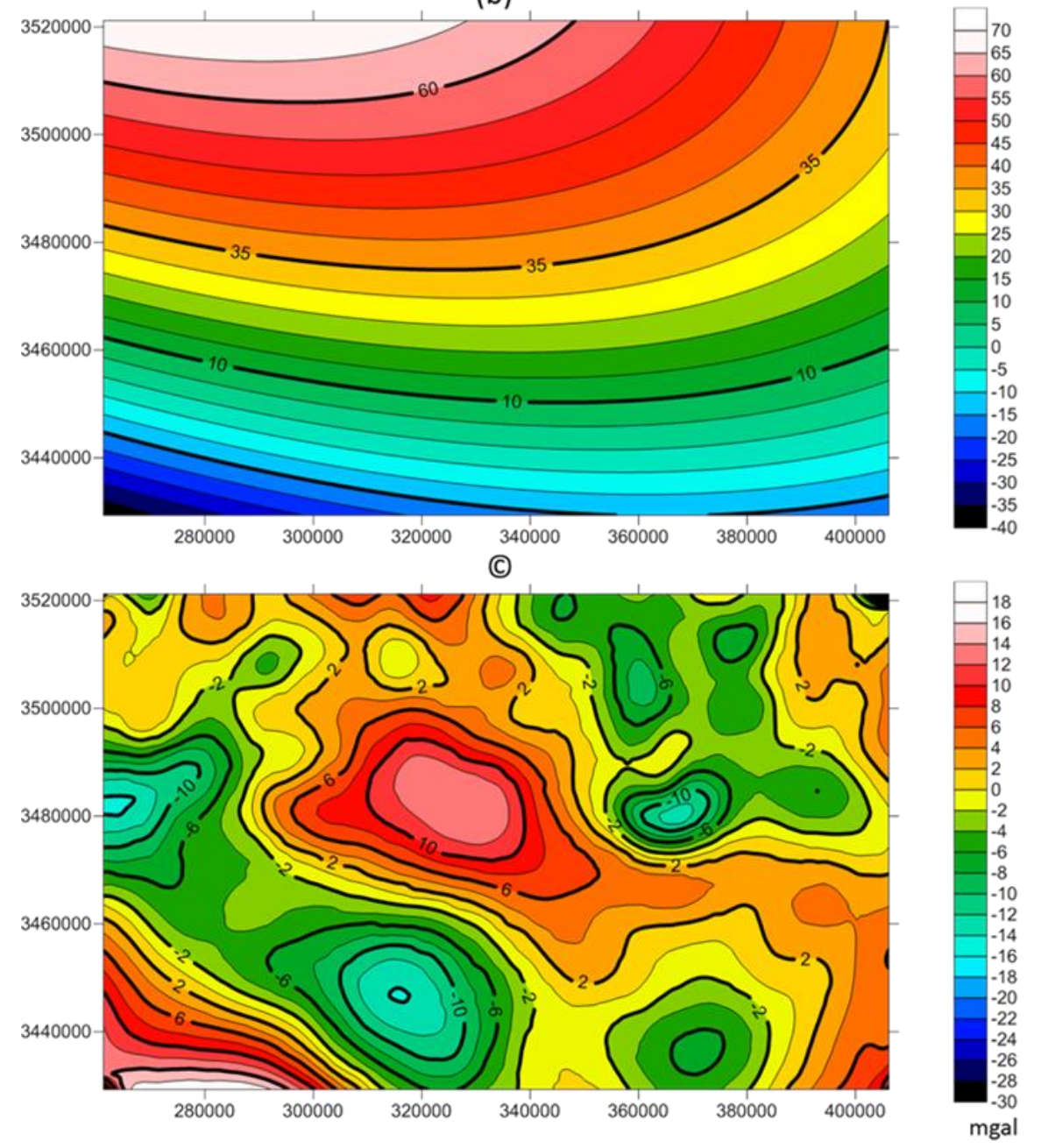

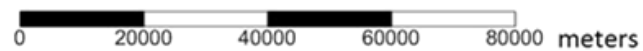

Figure (3): (a) Gravity anomaly map of the study area (after Sandwell satellite-derived gravity data) (b) Least-squares second order polynomial regional map and (c) is least square second order polynomial residual map. 


\section{Euler deconvolution method}

The aim of 3D Euler deconvolution processing is to create single or more maps that expose the locations and depths of the sources of potential field anomalies. In practice, when we wish to get results for a contact model with gravity data, an index of 0.5 must be often applied instead of an index of 0 to obtain reasonable results. A solution, is to work with the first vertical derivative of the gravity field in place of the original gravity field, this increases the rate of falloff by one power (one SI) and make the gravity SI equivalent to the magnetic SI for the same model source (Thompson, 1982, Reid et al., 1990, Ravat, 1996, FitzGerald et al. 2004 and Chenrai, et al., 2010). The four component grids provided to the 3D Euler system would then be:

$$
\frac{d g}{d z}, \frac{d^{2} g}{d z^{2}}, \frac{d^{2} g}{d z d x}, \frac{d^{2} g}{d z d y}
$$

In Euler interpretation, the correct SI is that which gives the tightest clustering of solutions, the window size should be large enough to incorporate a substantial variation of the field and field gradient, the window size should be small enough not to include significant effects from multiple sources, and for deeper sources it is better to increase the grid cell size rather than increasing the number of cells in the search window (Thompson, 1982, Reid et al. 1990, Ravat, 1996, FitzGerald et al., 2004 and Chenrai, et al., 2010). The input parameters used in Euler deconvolution, which give the optimal interpretation, are presented in Figure (4). Figures (4 and 5) represent the primarily interpreted structural framework of the study area.

The detected fault systems interpreted from the analysis of the gravity map by Euler deconvolution, are grouped into six major tectonic trends.

$\begin{array}{ll}\text { 1- } & \text { Mediterranean trend }(\mathrm{E}-\mathrm{W}) . \\ 2- & \text { Syrian arc trend }\left(\mathrm{N} 45^{\circ}-65^{\circ} \mathrm{E}\right) . \\ 3- & \text { Najd trend }\left(\mathrm{N} 65^{\circ} \mathrm{W}\right) . \\ 4- & \text { Suez trend }\left(\mathrm{N} 35^{\mathrm{o}}-45^{\circ} \mathrm{W}\right) . \\ 5- & \text { Aqaba trend }\left(\mathrm{N} 15^{\circ}-25^{\circ} \mathrm{E}\right) . \\ \text { 6- } & \text { North African trend }(\mathrm{N}-\mathrm{S}) .\end{array}$

These trends are graphically plotted as block diagrams (Fig. 6) and as a histogram (Fig. 7). The main predominated trend is the Mediterranean trend.

\section{Depth estimation by Euler deconvolution}

Basement depth maps constructed by Euler deconvolution have been presented in Figures (8 to 10). These maps reflect that the depth to the basement surface increases regularly from the southern and northern areas towards the central parts. Broadly speaking, we can realize a huge basin 
located in the midway portion of the surveyed area, where the depth reaches to its utmost value in central part reaching $10460 \mathrm{~m}$. The depth decreases gradually outside the basin in all directions, reaching $1400 \mathrm{~m}$.

\section{Depth estimation by half maximum amplitude}

The depth has been estimated on a net of profiles (100 X and $64 \mathrm{Y})$ on the second order residual map. The depths, along all profiles, are put up on the base map and contoured to give depth map patterns of the region (Fig. 11). This map reflects that the depth to the basement surface increases regularly towards the central part. Generally, a huge basin is located in the middle part of the study area, where the depth reaches to its maximum value $10,400 \mathrm{~m}$ in the central area.

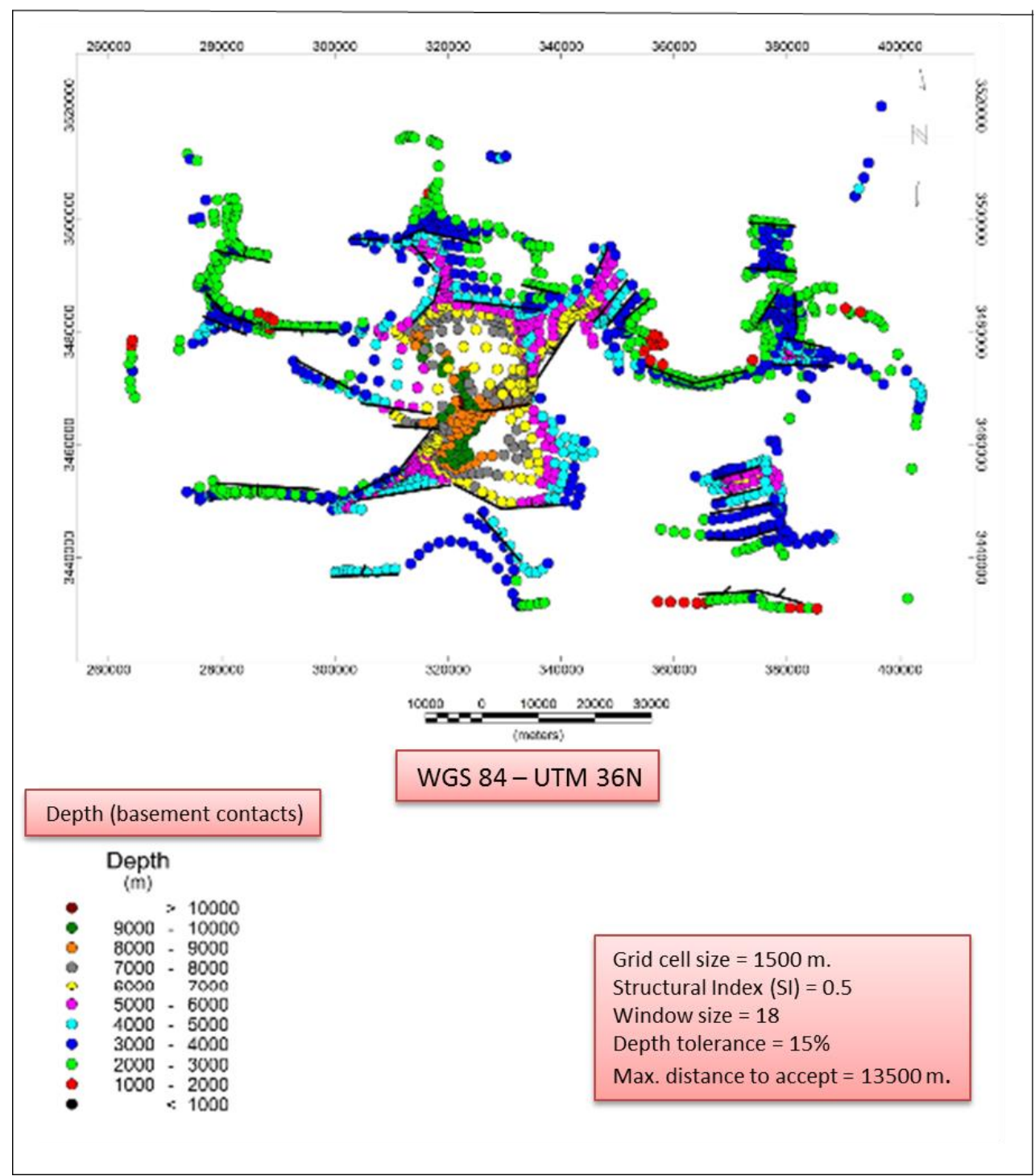

Figure (4): Estimated source locations and depth estimation performed by Euler deconvolution. 


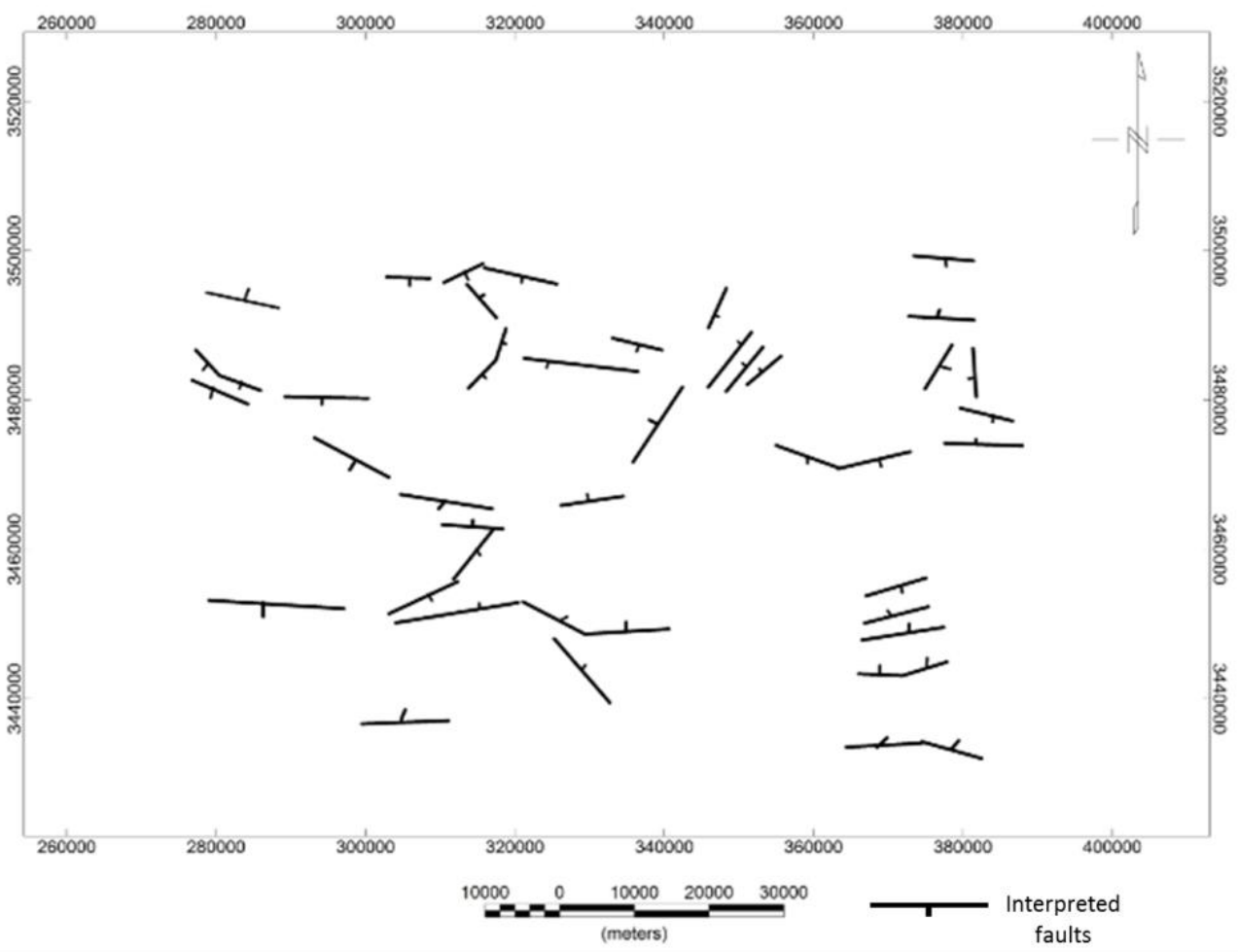

Figure (5): Structural framework (contacts or faults) on the basement surface.

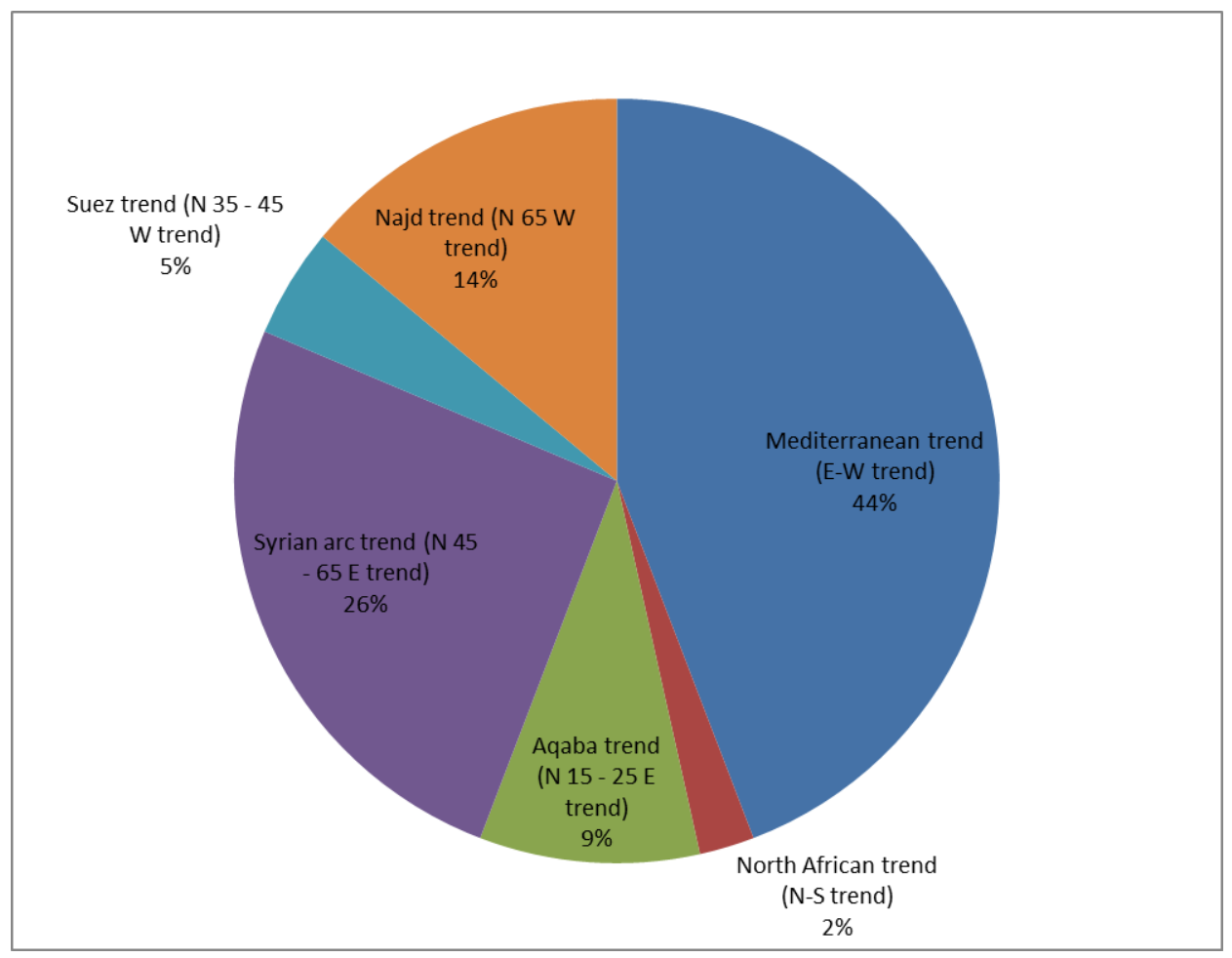

Figure (6): Distribution of the trend analysis performed by Euler deconvolution method. 


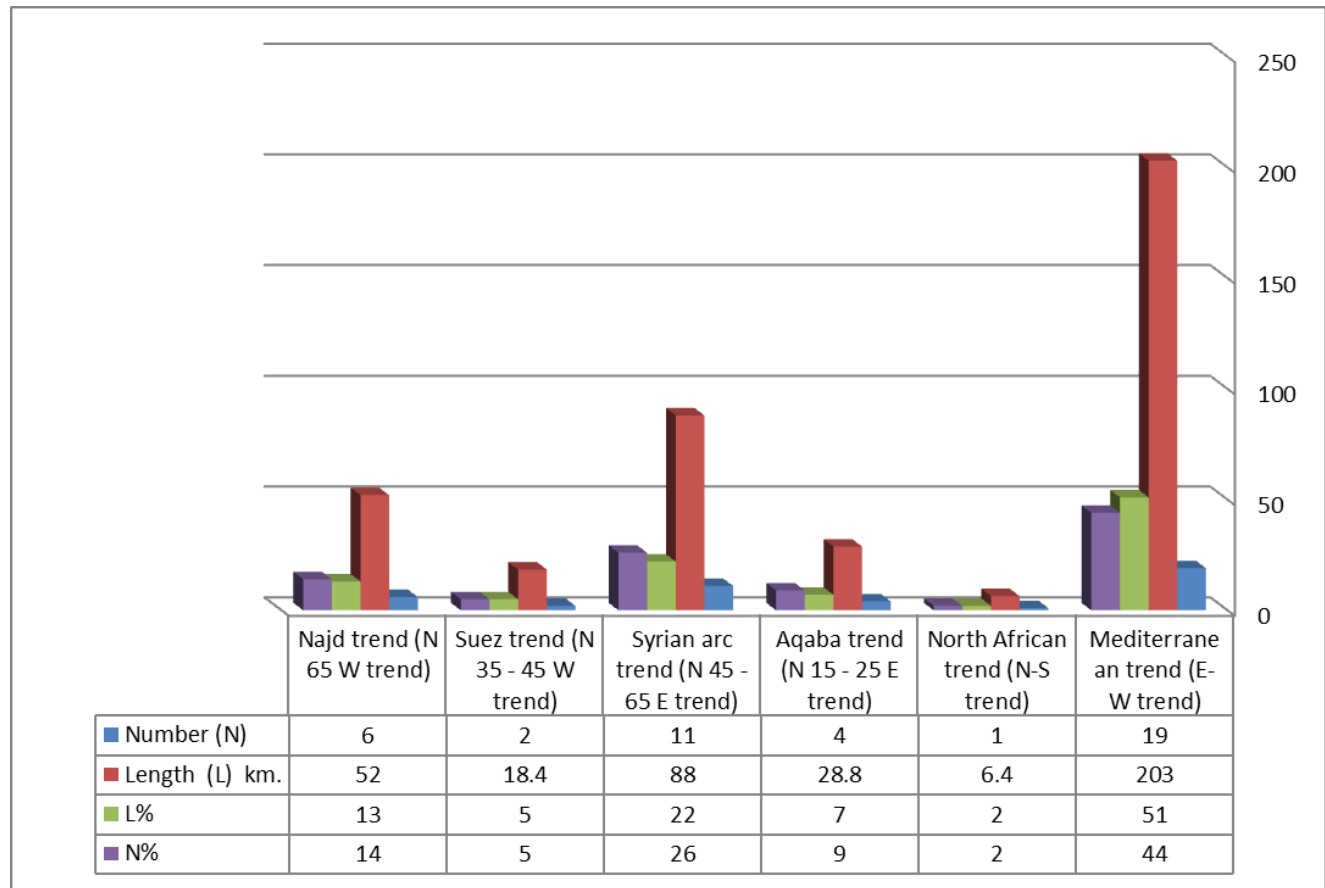

Figure (7): Diagram for the trend analysis performed by Euler deconvolution method.

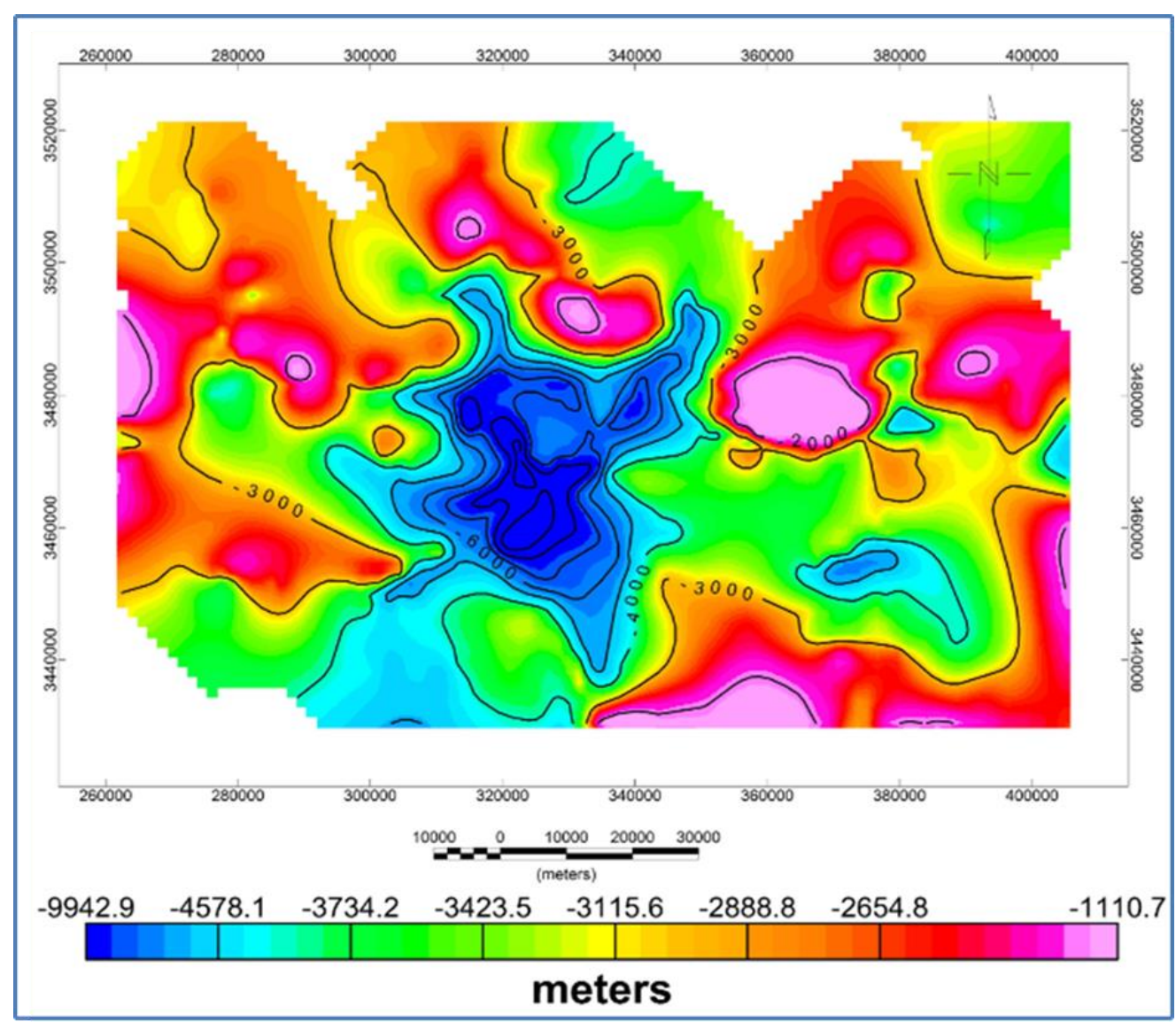

Figure (8): Depth to basement map performed by Euler deconvolution. 


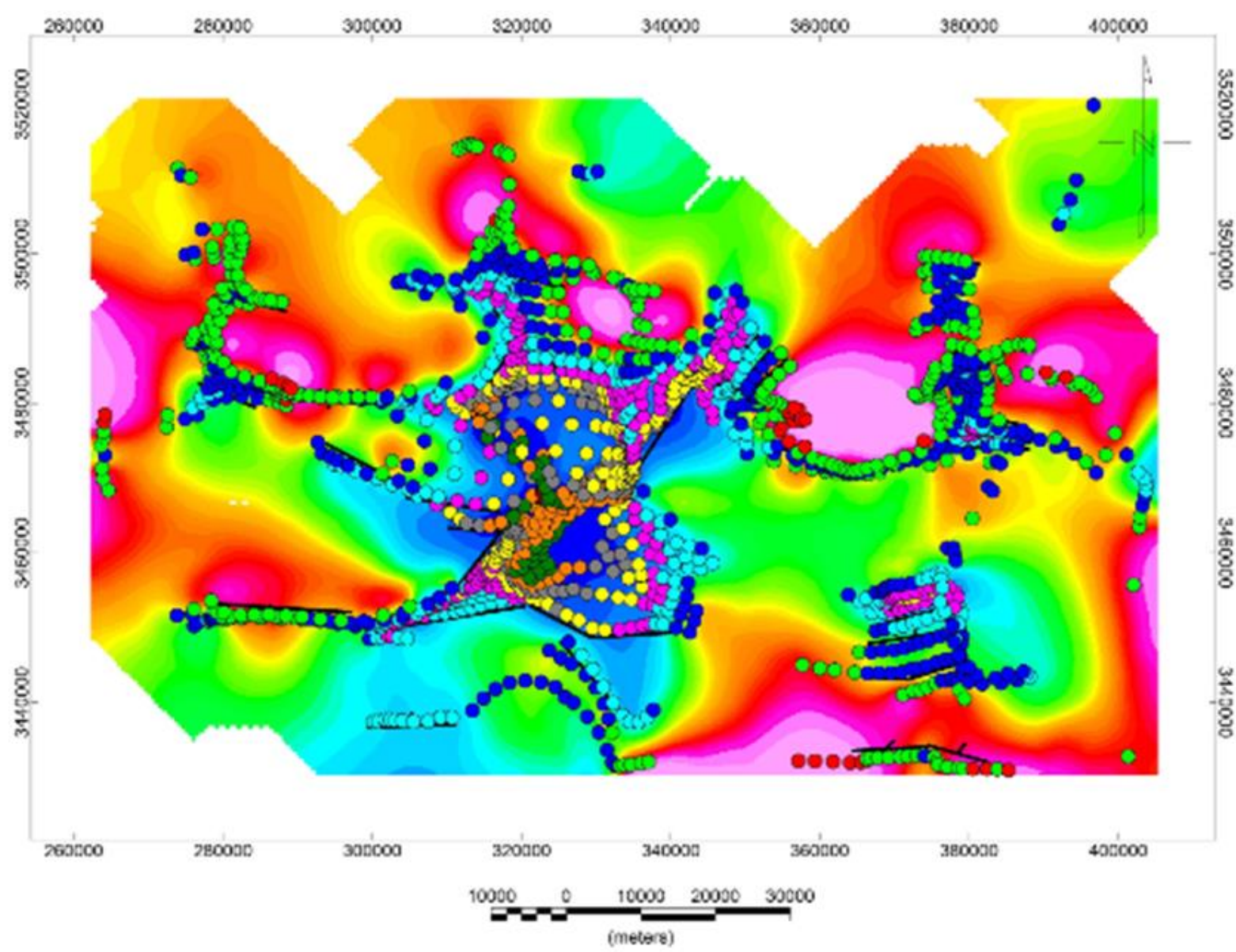

\begin{tabular}{|l|llllllllll}
-9942.9 & -4606.2 & -3743.3 & -3432.7 & -3119.9 & -2889.8 & -2661.8 & -1101.1 \\
\hline & & & & & & & & & \\
\hline
\end{tabular}

Depth

\section{Depth in meters}

(m)

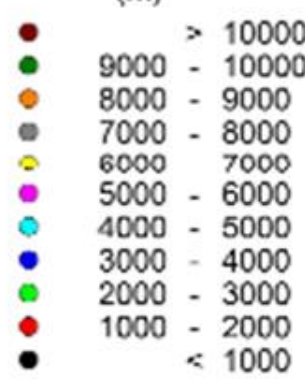

Figure (9): Estimated source locations posted on the basement depth map. 


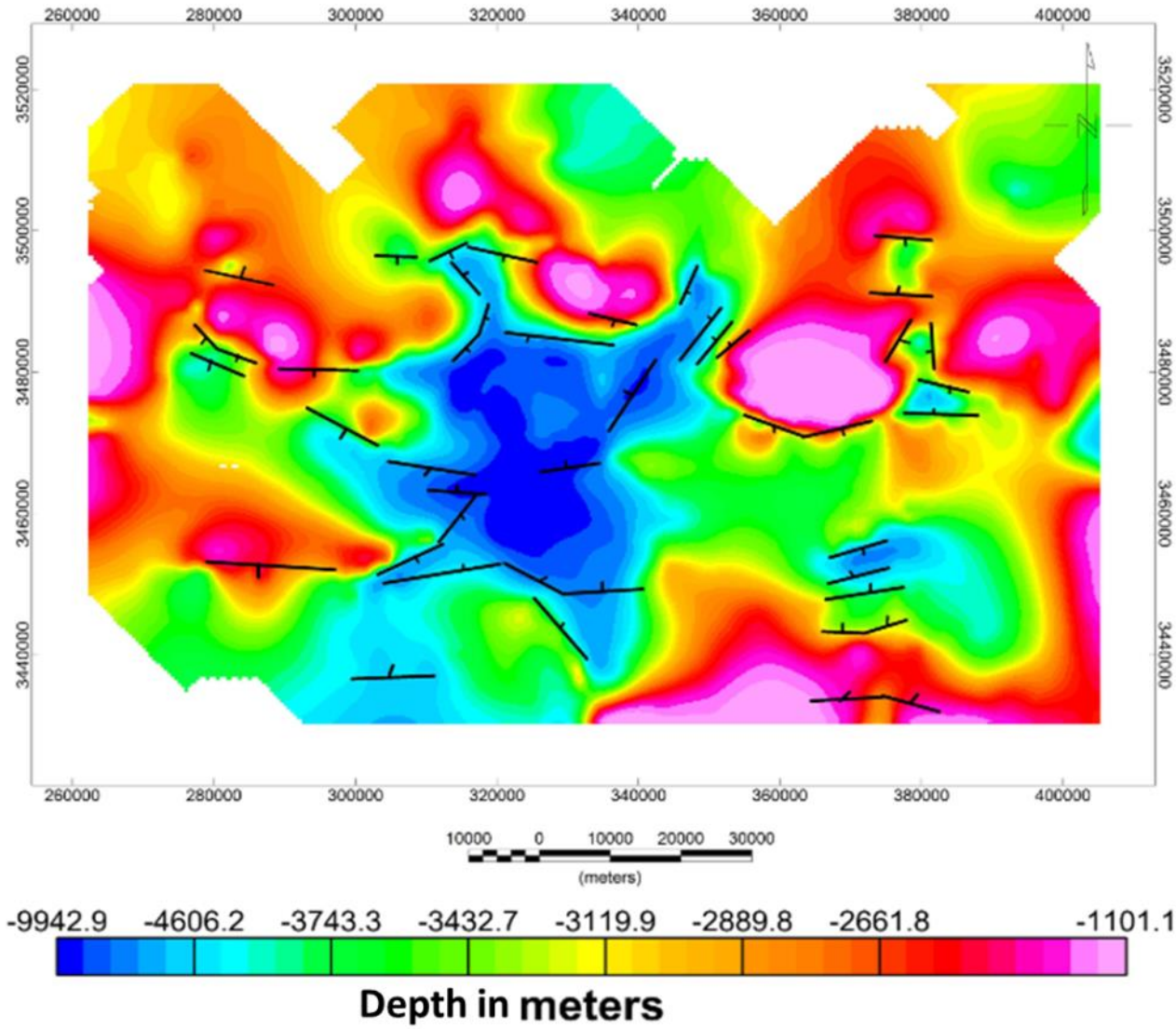

Figure (10): Contact (or faults) locations on the basement depth map.

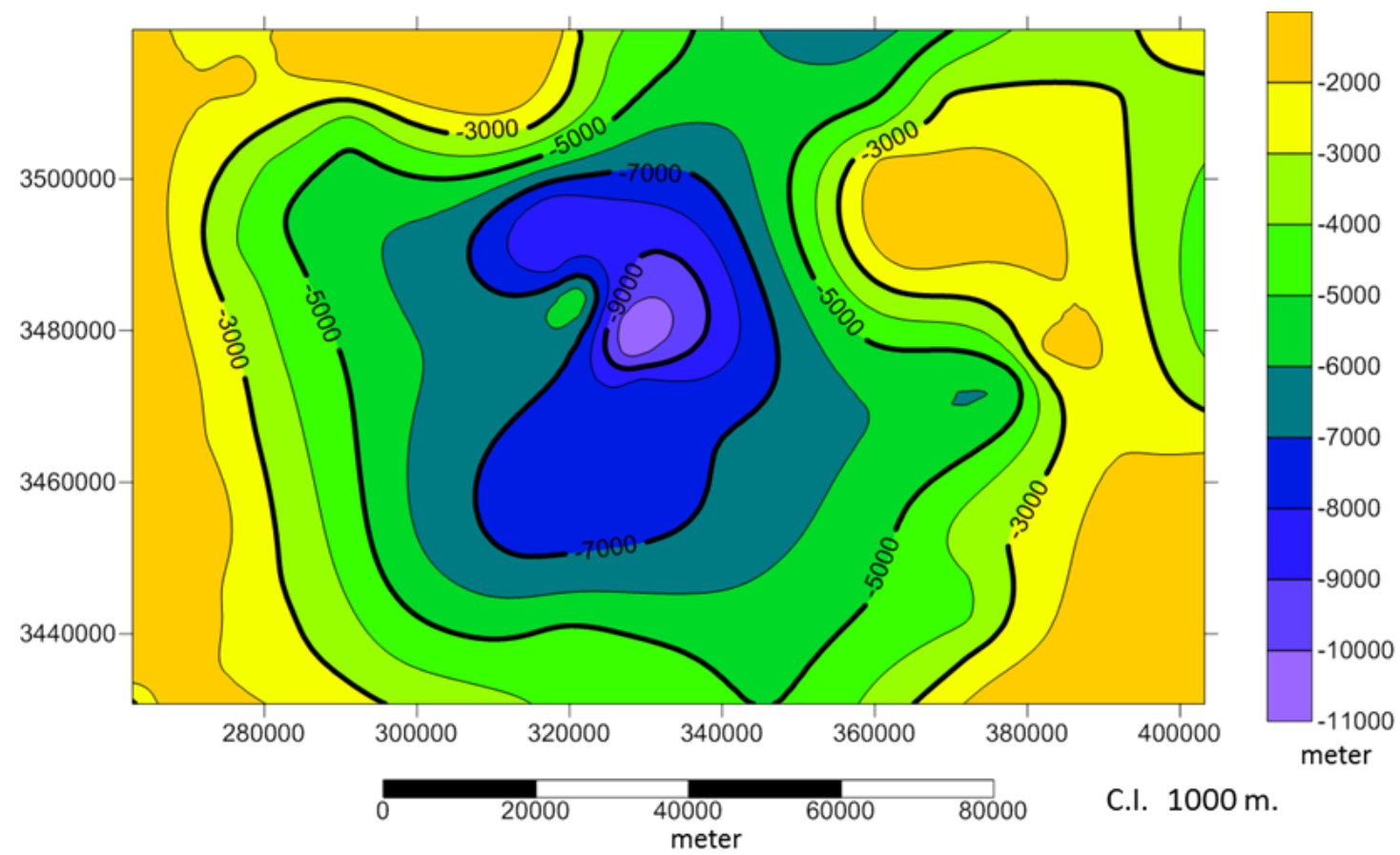

Figure (11): Depth to basement map performed by half maximum amplitude method. 


\section{Conclusion}

The study area is located in the northern part of the Nile Delta between Longitude $30^{\circ} 30^{\prime \prime}-32^{\circ} 00^{\prime \prime} \mathrm{E}$ and Latitude $31^{\circ} 00^{\prime \prime}-31^{\circ} 48^{\prime \prime} \mathrm{N}$. The gravity data of the study area are processed and interpreted to delineate the structural framework and to estimate the depth to the basement surface.

The Least-squares polynomial method is performed to separate the gravity anomaly of the study area into the regional and residual components. The second order polynomial is selected as the optimum one to represent the regional residual separation in the area. The second order residual map shows two elongated negative anomalies located in the southwestern and northeastern parts and one elongated positive anomaly. The three anomalies are trending northwest- southeast.

The fault systems detected from the Euler deconvolution of the gravity map are grouped into six major tectonic trends: Mediterranean trend (E-W), Syrian arc trend $\left(\mathrm{N} 45^{\circ}-65^{\circ} \mathrm{E}\right)$, Najd trend $\left(\mathrm{N} 65^{\circ} \mathrm{W}\right)$, Suez trend $\left(\mathrm{N} 35^{\circ}-45^{\circ} \mathrm{W}\right)$, Aqaba trend $\left(\mathrm{N} 15^{\circ}-25^{\circ} \mathrm{E}\right)$ and North African trend (N-S).

The depth estimation has been done by two methods; half maximum amplitude and Euler deconvelution. The two methods indicate that the depth to the basement surface increases regularly towards the central part. Huge basin is situated in the midway portion of the survey area, where the depth reaches its utmost value $10460 \mathrm{~m}$. The similarity of the estimated depth values from Euler deconvolution and half maximum amplitude methods suggests the reliability of these results.

\section{References}

Abdel-Gawad, M. (1969) New evidence of transcurrent movements in Red sea area and petroleum implications: Am. Assoc. Petroleum Geologists Bull., Vol. 53, No. 7, pp. 1466-1479.

Abdel Rahman, E.M.; Riad, S.; Refai, E. and Amin, Y. (1985) On the Leastsquares residual anomaly determinations. Geophys., Vol. 50, pp. 473-480.

Abdel Rahman, E.M.; Bayoumi, A.L. and El-Araby, H.M. (1991) Short note, least- square minimization approach to invert gravity data. Geophys., Vol. 56, pp. 115-118.

Azzam, A.S. (1994) An integrated seismo-facies and seismo-tectonic Study of the Nile Delta of Egypt, utilizing common-depth seismic reflection data. Ph.D. Thesis, Geology Department, Faculty of Science, Ein Shams University, Cairo, Egypt, 240 p.

Barakat, M. and Dominik, W. (2010) "Seismic Studies on the Messinian Rocks in the Onshore Nile Delta, Egypt" EAGE June 2010, pp. 14 - 17. 
Chenrai, P.; Meyers, J. and Charusiri, P. (2010) Euler Deconvolution Technique for Gravity Survey. Journal of Applied Sciences Research, Vol. 6 (11): pp. 1891-1897.

Delury, D.B. (1950) Values and integrals of the orthogonal polynomials up to $\mathrm{n}=26$, University of Toronto Press.

Dobrin, M.B. (1976) Introduction to geophysical prospecting Mc Graw- Hill Publ. Co., New York, 630 p.

El-Gezeery, M.N.; Mohsen, S.M. and Farid, M.I. (1972) Sedimentary basins in Egypt and their Petroleum prospects. - $8^{\text {th }}$ Arab Pet. Cong., Algiers, Vol. 2, No. 83, pp. 1-13.

Egyptian General Petroleum Corporation (1994) Nile Delta and north Sinai fields, discoveries and hydrocarbon potentialities (as comprehensive overview). EGPC-Cairo, Egypt, 387 p.

El-Heiny, I. and Enani, H. (1996) Regional stratigraphic interpretation pattern of Neogene sediments, Northern Nile Delta. - Egypt. $13^{\text {th }}$ Exploration and production conference, EGPC, Cairo, Egypt, pp.

El-Shazly, E.M. (1966) structural development of Egypt, U.A.R... Geol. Soc. Egypt prog. and Abst., pp. 31-38.

FitzGerald, D.; Reid, A. and McInerneya, PH. (2004) New discrimination techniques for Euler deconvolution. Computers \& Geosciences 30, pp 461-469.

Grant, F.S. (1957) A problem in the analysis of geophysical data. Geophys. Vol. 22, pp. 309-344.

Harms, J. and Wray, J. (1990) Nile Delta - In: R. Said, (Ed.): Geology of Egypt, A. A. Balkema/Rotterdam/Brookfield pp. 329-343.

Kamel, H.; Eita, T. and Sarhan, M. (1998) Nile Delta hydrocarbon potentialities. - 14th Exploration and production Conf., EGPC, Cairo, pp. 485-503.

Kostandi, A.B. (1959) Facies maps for the study of the Palaeozoic and Mesozoic sedimentary basins in the Egypt region. $1^{\text {st }}$ Arab Pet. Cong., Egypt, $12 \mathrm{p}$.

Logachive, A.A. (1968) Magnetic prospecting (in Russian) Leningrad, Mir Publisher, Moscow, $75 \mathrm{p}$.

Meshref, W.M. and El-Sheikh, M.M. (1973) Magnetic tectonic trend analysis in northern Egypt. Egypt J. Geol. Vol. 17, No. 2, pp. 179-184.

Meshref, W.M.; Refai, E.M.; Sadek, H.S.; Abdel-Baki, S.H.; El-Sirafy, A.M.; El-Kattan, E.I.; El-Meliegy, M.A. and El-Sheikh, M.M. (1980) Structural geophysical interpretation of basement rocks of the northeastern desert of Egypt. Geol. Surv. Egypt, Annals, Vol. 10, pp. 923-937. 
Meshref, W.M. (1982) Regional structural setting of northern Egypt. $6^{\text {th }}$ Explor. Semin., Cairo, Egypt. 22 p.

Nettleton, L.L. (1976) Gravity and magnetic in oil exploration. New York. Mc. Graw. Hill Publ. Co., 464 p.

Oldham C.H.G. and Southerland, D.B. (1955) Orthogonal polynomials, their use in estimation the regional effect, Geophys., Vol.20, pp.295-306.

Ravat D. (1996) Analysis of the Euler method and its applicability in environmental magnetic investigations. Journal of Environmental Engineering Geophysics, vol. 1, pp. 229-238.

Reid, A.B.; Allsop, J.M.; Granser, H.; Millett, A.J. and Somerton, I.W. (1990) Magnetic interpretation in three dimensions using Euler deconvolution. Geophys., Vol. 55, pp. 80-91.

Rizzini, A.; Vezzani, F.; Cococcetta, V. and Milad, G. (1978) Stratigraphy and sedimentation of Neogene- Qaternary section in the Nile Delta area. - Marine Geology Vol. 27, pp. 327-348.

Robinson, E.S. (1988) Basic Exploration Geophysics. John Wiley and Sons, New York, Chichester, Brisbane, Toronto, Singapore.

Said, R. (1962) The Geology of Egypt, Elsevier, New York- 377 p.

Said, R. (1973) Evaluation of Eocene -Miocene Sedimentation Patterns in Parts of Northern Egypt: AAPG Bull., Vol. 60, pp. 34-64.

Said, R. (1990) The Geology of Egypt. A Balkema Publishers, USA- 734 p.

Salem. M. (1976) Evolution of the Eocene-Miocene sedimentation pattern in northern Egypt. - AAPG-Bull. Vol. 60, pp. 34-64.

Schlumberger (1984) Geology of Egypt, Paper presented at the Well Evaluation Conference, Schlumberger, Cairo, pp. 1-64.

Shata, A. and El-Fayoumy, I. (1970) Remarks on the Regional Geological Structure of the Nile Delta. In: Hydrology of Deltas. IANSHIUNESCO Bucharest symposium. Vol. I. UNESECO. Paris, pp. 189-197.

Thompson, L. (1986) Weak elastic anisotropy. Geophys. Prosp. Vol. 51, pp. 1954-1966.

Youssef, M.I. (1968) Structural pattern of Egypt and its interrelation. Bull. AAPG. USA. Vol. 52, No. 4, pp. 601 - 614.

Zaghloul, Z.M.; Taha, A.A. and Gheith, A.M. (1977a) Microfacies studies and paleoenvironmental trends on the subsurface sediments of Kafr El Sheikh Well No.1, Nile Delta area - Bull. Mansoura Uni. Vol.5, pp.113138.

Zaghloul, Z.M.; Taha, A.A.; Hegab, O. and El Fawal, F. (1977b) The Neogene-Quaternary sedimentary basins of the Nile Delta, Egypt J.Geol. Vol.21, pp.1-19. 
Zaghloul, M.Z.; Shaaban, F.F. and Yousef, A.F. (1999) Mesozoic and Cenozoic Sedimentary Basins, Nile Delta, Egypt. - Proc. of the $1^{\text {st }}$ International Symp. Mansoura. Univ. Egypt: pp. 13-20. 
ملخص

هذه الدراسة محاولة لتحديد الإطار الهيكلي الإقليمي وتكاويين الاحواض الرسوبية لثمال دلتا النيل، مصر من خلال تحليل خريطة الجاذبية. تقع منطقة الدراسة بين خطى طول 30" 032 00 - 00 شرقا وخطى عرض 00" o31 - 48" o31 شمالا. تم استخدام تقنية متعدد الحدود لفصل خريطة الجاذبية لمنطقة الدراسة إلى مكوناتها الإقليمية والمتبقية. تم تحديد الترتيب الثاني لمتعددات الحدود واعتباره الخيار الأمثل لتحقيق الفصل المتبقي والإقليمي. تم تحديد الإطار الهيكلي للأحواض الرسوبية باستخدام تقنية ستاندرد ايولر ديكونفيليوشين، وتتجمع أنظمة الفو الق المكتشفة في ستة اتجاهات تكتونية رئيسية هى: اتجاه البحر المتوسط (اتجاه شرق - غرب)، و اتجاه القوس السوري (اتجاه 45ه شمال 65 شرق)، اتجاه نجد (اتجاه شمال 65o غرب)، اتجاه خليج السويس (اتجاه شمال 35035 غرب)، اتجاه العقبة (اتجاه شمال 15o - 25o شرق) و اتجاه شمال أفريقيا (اتجاه شمال - جنوب). وتوضح خريطة العمق وجود حوضا كبيرا يقع في الجزء الأوسط من منطقة الدراسة. ينراوح عمق صخور القاعدة فى هذا الحوض من 1400 م إلى 10460 م. 